\title{
Stereotactic ablative body radiotherapy combined with immunotherapy: Present status and future perspectives
}

Citation for published version (APA):

Rekers, N. H., Troost, E. G. C., Zegers, C. M. L., Germeraad, W. T. V., Dubois, L. J., \& Lambin, P. (2014). Stereotactic ablative body radiotherapy combined with immunotherapy: Present status and future perspectives. Cancer Radiotherapie, 18(5-6), 391-395. https://doi.org/10.1016/j.canrad.2014.06.012

Document status and date:

Published: 01/10/2014

DOI:

10.1016/j.canrad.2014.06.012

Document Version:

Publisher's PDF, also known as Version of record

Document license:

Taverne

Please check the document version of this publication:

- A submitted manuscript is the version of the article upon submission and before peer-review. There can be important differences between the submitted version and the official published version of record.

People interested in the research are advised to contact the author for the final version of the publication, or visit the DOI to the publisher's website.

- The final author version and the galley proof are versions of the publication after peer review.

- The final published version features the final layout of the paper including the volume, issue and page numbers.

Link to publication

\footnotetext{
General rights rights.

- You may freely distribute the URL identifying the publication in the public portal. please follow below link for the End User Agreement:

www.umlib.nl/taverne-license

Take down policy

If you believe that this document breaches copyright please contact us at:

repository@maastrichtuniversity.nl

providing details and we will investigate your claim.
}

Copyright and moral rights for the publications made accessible in the public portal are retained by the authors and/or other copyright owners and it is a condition of accessing publications that users recognise and abide by the legal requirements associated with these

- Users may download and print one copy of any publication from the public portal for the purpose of private study or research.

- You may not further distribute the material or use it for any profit-making activity or commercial gain

If the publication is distributed under the terms of Article $25 \mathrm{fa}$ of the Dutch Copyright Act, indicated by the "Taverne" license above, 
Review

\title{
Stereotactic ablative body radiotherapy combined with immunotherapy: Present status and future perspectives
}

\section{Association de radiothérapie stéréotaxique ablative et d'immunothérapie : présent et avenir}

\author{
N.H. Rekers ${ }^{\mathrm{a}, *, 1}$, E.G.C. Troost ${ }^{\mathrm{a}, 1}$, C.M.L. Zegers ${ }^{\mathrm{a}}$, W.T.V. Germeraad ${ }^{\mathrm{b}}$, L.J. Dubois $^{\mathrm{a}}$, \\ P. Lambin ${ }^{\mathrm{a}}$ \\ a Department of radiation oncology (MaastRO Lab), GROW-School for oncology and developmental biology, Maastricht university medical center, UNS \\ 50/23, PO Box 616, 6200 MD Maastricht, The Netherlands \\ ${ }^{\mathrm{b}}$ Department of internal medicine, GROW-School for oncology and developmental biology, Maastricht university medical centre, UNS 50/23, PO Box 616, \\ 6200 MD Maastricht, The Netherlands
}

\section{A R T I C L E I N F O}

Keywords:

Stereotactic ablative body radiotherapy

Immunotherapy

\begin{abstract}
A B S T R A C T
Radiotherapy is along with surgery and chemotherapy one of the prime treatment modalities in cancer. It is applied in the primary, neoadjuvant as well as the adjuvant setting. Radiation techniques have rapidly evolved during the past decade enabling the delivery of high radiation doses, reducing side-effects in tumour-adjacent normal tissues. While increasing local tumour control, current and future efforts ought to deal with microscopic disease at a distance of the primary tumour, ultimately responsible for diseaseprogression. This review explores the possibility of bimodal treatment combining radiotherapy with immunotherapy.
\end{abstract}

(C) 2014 Société française de radiothérapie oncologique (SFRO). Published by Elsevier Masson SAS. All rights reserved.

\section{R É S U M É}

La radiothérapie, conjointement avec la chirurgie et la chimiothérapie, est une thérapeutique majeure du cancer. Elle est délivrée dans la tumeur primitive en situation néo-adjuvante ou adjuvante. Les techniques de radiothérapie ont beaucoup évolué au cours de la dernière décennie en autorisant la délivrance de fortes doses et en réduisant les effets secondaires dans les tissus sains adjacents. Sans oublier le contrôle de la tumeur, des efforts doivent être faits pour contrôler la maladie macroscopique et celle à distance, qui est finalement responsable de la progression tumorale. Cette revue traite de la possibilité d'association de radiothérapie et d'immunothérapie.

@ 2014 Société française de radiothérapie oncologique (SFRO). Publié par Elsevier Masson SAS. Tous droits réservés.

\section{Stereotactic ablative body radiotherapy}

Stereotactic ablative body radiotherapy is a form of highprecision radiotherapy delivering extremely high ablative doses of radiation, usually in three to eight fractions, combining reproducible patient immobilization, tumour motion tracking and

\footnotetext{
* Corresponding author.

E-mail address: nicolle.rekers@maastrichtuniversity.nl (N.H. Rekers).

${ }^{1}$ Equal contribution.
}

steep dose gradients, resulting in reduced normal tissue toxicity [1]. Stereotactic ablative body radiotherapy achieves excellent local control rates in patients with stage I/II non-small cell lung cancer and liver metastases of colorectal cancer [2]. Nowadays, these favourable results of stereotactic ablative body radiotherapy are being transferred to patients with limited sites of metastatic disease (oligometastatic; five or less metastases in no more than three organs) originating from solid tumours (e.g., breast, non-small cell lung cancer, head and neck, renal cell carcinoma, melanoma, colorectal cancer), both at primary diagnosis (synchronous) and during the course of disease [3-10]. Tree et al. reports on favourable 
local control rates of approximately $80 \%$ using stereotactic ablative body radiotherapy with few treatment-related side-effects [10]. Recently, our group found patients suffering from non-small cell lung cancer with synchronous oligometastases to have a median progression-free survival of 12.1 months when treated radically to all known metastatic sites [11]. However, in the vast majority of patients, disease-progression at distance from the treated site occurs ultimately leading to extensive metastatic disease and cancer-related death.

\section{Tumorigenesis and the immune system}

The immune system closely monitors the process of tumorigenesis first by registering the presence of cells undergoing neoplastic transformation, and second by interacting with neoplastic cells to mediate their destruction. Solid tumours have developed mechanisms to escape "cancer immunosurveillance", i.e., detection by the immune system. This is achieved by, among other mechanisms, the secretion of potent immune-suppressive cytokines and the expression of $\mathrm{T}$ cell inhibitory molecules, which are able to down-regulate an anti-tumour immune response [12]. There is conclusive evidence that, apart from its direct effects, radiotherapy can induce "immunogenic cell death", which serves as a trigger or "in situ vaccine" for the innate and adaptive immune system [13-15]. Radiotherapy induces immunogenic cell death by the release of tumour antigens and damage-associated molecular patterns (DAMPS), including high-mobility group protein B1 (HMGB1), adenosine triphosphate (ATP) and the exposure of calreticulin on the tumour cell surface. Also, several cellular surface expression molecules, including Fas and ICAM-1, are upregulated $[16,17]$. These factors promote uptake of dying cells by dendritic cells, cross-presentation of tumour antigens to T cells, and activation of anti-tumour (cytotoxic) T cells [18,19] (Fig. 1).

Recent preclinical and clinical data indicate that immunogenic cell death may be an important consequence of ionizing radiation and that localized radiotherapy can evoke and/or modulate tumour-associated immune responses $[18,20]$. Even though clinical evidence of systemic anti-tumour response from local irradiation is scarce, tumour regression outside the irradiated field was already recognized in 1953 and termed abscopal effect [21-25]. In general, it is unlikely that radiotherapy alone provides a sufficient anti-tumour immune response and the addition of active immunotherapy to stereotactic ablative body radiotherapy may increase the therapeutic potential and induce abscopal effects in a more systematic way $[24,26]$.

\section{Recent clinical successes using immunotherapy}

\subsection{Breaking the immune tolerance using checkpoint modulators}

Immune-checkpoints refer to a plethora of inhibitory pathways hardwired into the immune system. These are crucial for maintaining self-tolerance and modulating the duration and amplitude of physiological immune responses in peripheral tissues, in order to minimize collateral tissue damage. It is now clear that tumours use certain immune-checkpoint pathways as a major mechanism of immune resistance, particularly against tumour antigen specific $T$ cells. Examples of these immune-checkpoints are the cytotoxic $\mathrm{T}$ lymphocyte-associated antigen 4 (CTLA-4), or the programmed death receptor 1 (PD-1) and its ligand PD-L1. New strategies aim at breaking this tolerance.

Monoclonal antibody-mediated (ipilimumab) blockade of CTLA4 on T cells seems to be sufficient to elicit an effective anti-tumour immunity [27], which paved the way for clinical studies. Two-phase III studies evaluated the clinical effects of ipilimumab in metastatic melanoma patients. Treatment with ipilimumab as monotherapy improved median overall survival rates from 6.4 to 10 months [28], and bimodal treatment with standard of care chemotherapy (dacarbazine) increased 3-year overall survival from $12.2 \%$ to $20.8 \%$ [29]. Although the percentage of patients responding to ipilimumab was limited (complete response $\sim 1 \%$, partial response in $5-10 \%$ ), the effects of response were long-lasting in those who responded. Even though treatment-related adverse effects occurred in almost all patients, with several immune effects-related deaths in the first trial, and despite the high costs, ipilimumab received FDA approval in 2011 for treatment of advanced melanoma patients due to its clear clinical effect.

\subsection{Immunotherapy for other solid tumours}

The effect of immunotherapy has increasingly been evaluated in both immunogenic and non-immunogenic (metastatic) solid tumours, including prostate cancer, renal cell carcinoma, melanoma, and head and neck cancer. In the subsequent paragraph the diversity and recent merits of this approach are highlighted.

The autologous active cellular immunotherapy, Sipuleucel-T, significantly reduced the risk of death in patients suffering from metastatic castration-resistant prostate cancer compared to the placebo group [30]. Also, prostate-specific antigen (PSA)-targeted poxviral vaccines were well tolerated and associated with an 8.5-month improvement in median overall survival for patients with metastatic castration-resistant prostate cancer [31]. Recent advances for metastatic castration-resistant prostate cancer were well summarized by Flemming [32].

Rini et al. randomized patients with metastastic renal cell carcinoma into two cohorts, one receiving bevacizumab plus interferon alpha (IFN- $\alpha$ ), the other IFN- $\alpha$ only [33]. The combination treatment led to a slightly prolonged overall survival time but did not meet expectations, i.e., it was impossible to identify patient subgroups benefiting from the combined treatment. Autologous cytokine-induced killer cell immunotherapy was found to be superior to combined IL-2 and IFN $\alpha$ treatment in terms of 3year progression-free survival and overall survival in patient with metastatic renal cell carcinoma [34].

For head and neck cancer patients, research efforts include the development of the vaccine DRibble, stimulating tumourinfiltrating T-lymphocytes [35] and immunotherapy of human papilloma virus (HPV)-associated head and neck cancer [36] amongst others.

\section{Stereotactic ablative body radiotherapy combined with immunotherapy}

\subsection{Preclinical results}

Several studies have focused on the immunogenic response of tumours to different dose schedules of radiotherapy. Lee et al. observed that a single dose of ablative radiotherapy (20 Gy) generated a CD8+ $\mathrm{T}$ cell-dependent immunity leading to tumour reduction and eradication of metastasis [37]. In comparison, mice treated with $4 \times 5 \mathrm{~Gy}$ initially responded to radiotherapy but tumours relapsed over time. One possible explanation is that fractionated low-dose radiotherapy may kill infiltrating CD8+ T cells over time. However, when ablative radiotherapy $(2 \times 12 \mathrm{~Gy})$ was combined with ad-LIGHT-based immunotherapy, circulating cytotoxic T cells increased again and micrometastases were eradicated [37]. Lugade et al. observed activated and expanded anti-tumour $\mathrm{CD} 8+\mathrm{T}$ cells in response to 5 fractions of $3 \mathrm{~Gy}$, however without resulting in tumour growth delay [38]. Although these studies indicate that ablative radiotherapy is able to provoke a CD8+ $\mathrm{T}$ cell mediated immune response, most studies only detected 


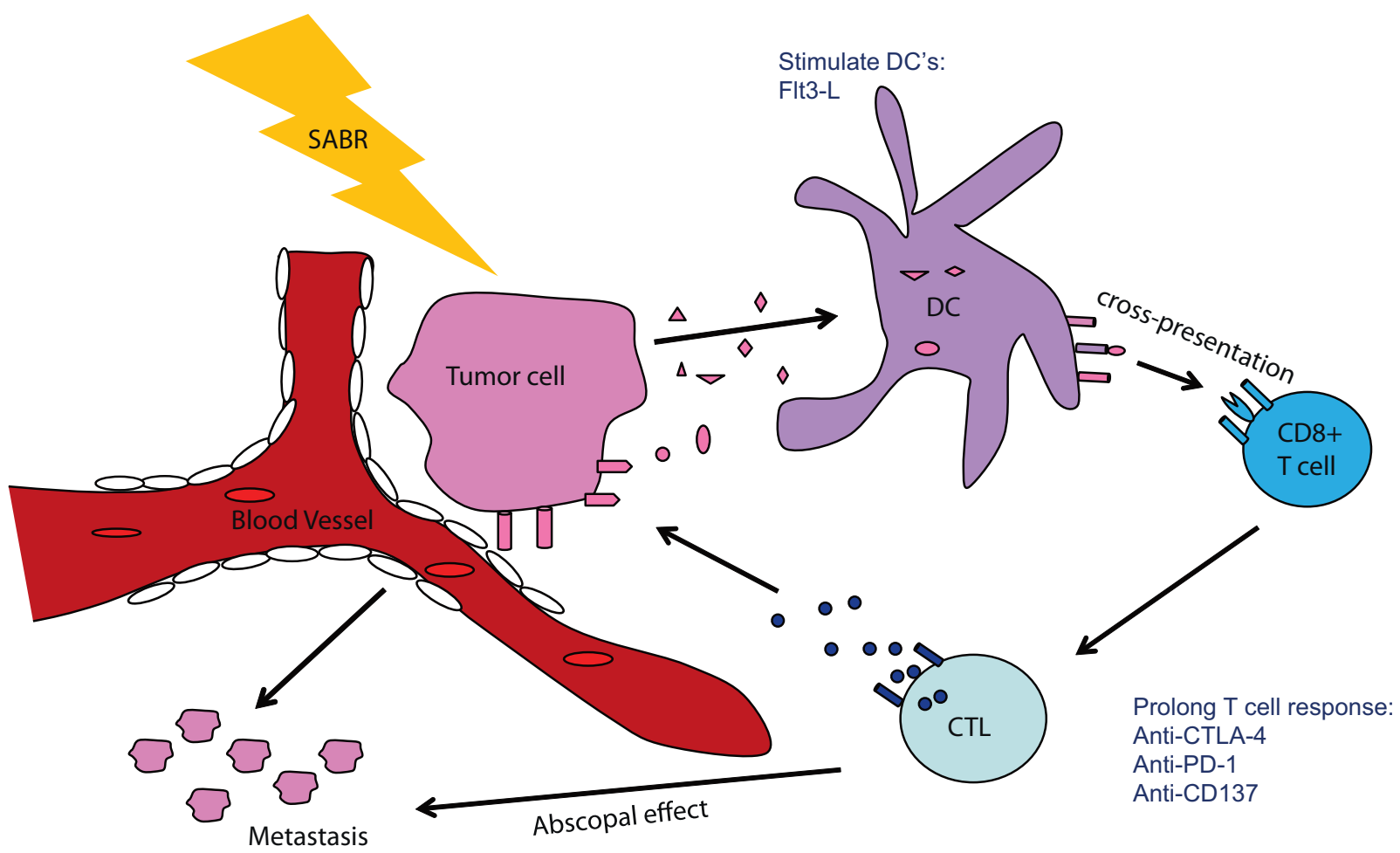

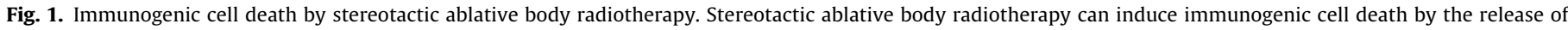

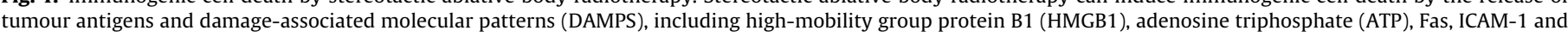

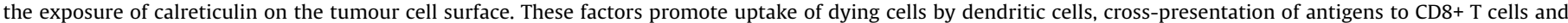

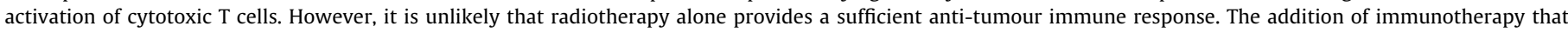

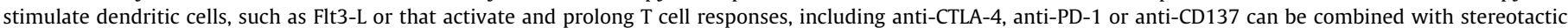

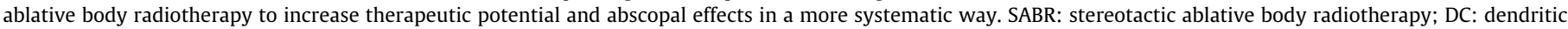
cell; CTL: cytotoxic T lymphocyte.

an immune response after radiotherapy combined with different immunotherapies.

Several in vivo studies have investigated the combination of radiotherapy with anti-CTLA-4 based immunotherapy. In a metastasizing breast cancer mouse model, a single dose (12 Gy) of radiotherapy to the primary tumour combined with systemic anti-CTLA-4 blocking antibody 9H10 immunotherapy decreased metastatic burden, but the effect on the primary tumours was minimal. Two radiotherapy fractions of $12 \mathrm{~Gy}$ delivered to the primary tumour in combination with CTLA-4 blockade resulted in complete regression of the irradiated tumour and metastases in the majority of the mice, a response which was CD8+ T cell mediated [39]. Dewan et al. tested different radiation regimens similar to stereotactic ablative body radiotherapy $(1 \times 20 \mathrm{~Gy}, 3 \times 8 \mathrm{~Gy}$ or $5 \times 6 \mathrm{~Gy})$ in combination with anti-CTLA-4 in two poorly immunogenic tumour models and observed a growth delay of the irradiated tumour in all treatment schedules [40]. However, an anti-tumour effect outside the radiation field (abscopal effect) was only observed for the combination of anti-CTLA- 4 with fractionated radiotherapy $(3 \times 8 \mathrm{~Gy})$.

Furthermore, Verbrugge et al. investigated a combination of antibodies against the immune modulators CD137 and PD-1, in combination with single dose ( $12 \mathrm{~Gy}$ ) or fractionated $(4 \times 4$ or $5 \mathrm{~Gy})$ radiotherapy in an orthotropic mice model [41]. Antibody combination therapy with single dose radiotherapy was effective and the combination with either $4 \times 4 \mathrm{~Gy}$ or $4 \times 5 \mathrm{~Gy}$ showed tumour rejection rates of $40 \%$ and $80 \%$, respectively. Furthermore, combination of single dose ( $12 \mathrm{~Gy}$ ) radiotherapy with anti-PD-L1 treatment activated a cytotoxic $\mathrm{T}$ cell response, which resulted in tumour regression. An additional explanation for the local tumour control is the reduction of local accumulation of myeloid-derived suppressor cells [42].
Additionally, radiotherapy has been shown to reduce tumour growth within and outside the radiation field when combined with the dendritic cell growth factor Flt3-L [43], the human macrophage inflammatory protein-1 alpha variant (ECI301) or with IL-2 administration [44-46]. Experiments with syngeneic tumour-bearing mice showed that blocking annexin A5 resulted in decreased dendritic cell clearance by macrophages, an improved tumour immunogenicity, and combination with radiotherapy led to an effective tumour growth inhibition [47]. Recently, radiotherapy combined with adenoviral-mediated vaccination against the colorectal cancer antigen GUCY2C resulted in a specific T cell response leading to tumour eradication [48].

\subsection{Clinical results}

There are limited clinical results on the combination of Stereotactic ablative body radiotherapy with immunotherapy. Postow et al. were the first to observe an anti-tumour immunologic rejection of a metastatic lesion at distance from the irradiated site and more reports followed [24,49-51]. In parallel, several phase II/III clinical trials have been conducted leading to recent publications. The phase I/II study in patients with metastatic castration-resistant prostate cancer found ipilimumab with or without radiotherapy to induce anti-tumour activity with disease control and manageable side-effects [52]. However, Kwon et al. randomized between ipilimumab or placebo after radiotherapy in patients with metastatic castration-resistant prostate cancer and found no difference in terms of overall survival [53]. Several clinical studies on combining immunotherapy (ipilimumab, PD-1 and PD-L1) with (stereotactic ablative body) radiotherapy in diverse solid tumours (i.e., melanoma, colorectal cancer, head and neck cancer, cervical 
cancer, (non-) small cell lung cancer, prostate and pancreatic cancer) are currently being conducted and results are awaited eagerly [54].

\section{Conclusion}

In conclusion, these data show that immunogenic cell death caused by different strategies of radiotherapy can be used in combination with immunotherapy to induce a CD8+ T cell mediated anti-tumour response, which leads to tumour control of the irradiated tumour and often to tumour control outside the radiation field, i.e., an abscopal effect in different preclinical models. However, there is not yet a uniform combination strategy for the best radiotherapy schedule/dose and immunotherapeutic approach. Furthermore, these preclinical studies often show no effect when immunotherapy is used without radiotherapy, suggesting that radiotherapy plays a key role as immunogenic trigger, which can be further enhanced when boosting the immune system. Clinical studies are focusing on different immunotherapies, often trying to activate or prolong specific anti-tumour $\mathrm{T}$ cell responses, showing promising responses. The administration of immunotherapy adjuvantly to radiotherapy thus activating or prolonging $\mathrm{T}$ cell responses specific to the irradiated tumour may increase the immune response inside the radiation field and at metastatic sides. Therefore, it may be important to start with a trigger received from stereotactic ablative body radiotherapy before administrating immunotherapy, because of the 'priming' role of radiotherapy in this anti-tumour process.

\section{Disclosure of interest}

The authors declare that they have no conflicts of interest concerning this article.

\section{References}

[1] Jaffray DA. Image-guided radiotherapy: from current concept to future perspectives. Nature reviews. Clin Oncol 2012;9:688-99.

[2] van Baardwijk A, Tomé WA, van Elmpt W, Bentzen SM, Reymen B, Wanders $\mathrm{R}$, et al. Is high-dose stereotactic body radiotherapy (SBRT) for stage I nonsmall cell lung cancer (NSCLC) overkill? A systematic review. Radiother Oncol 2012;105:145-9.

[3] Ashworth A, Rodrigues G, Boldt G, Palma D. Is there an oligometastatic state in non-small cell lung cancer? A systematic review of the literature. Lung Cancer 2013;82:197-203.

[4] Cheruvu P, Metcalfe SK, Metcalfe J, Chen Y, Okunieff P, Milano MT. Comparison of outcomes in patients with stage III versus limited stage IV non-small cell lung cancer. Radiat Oncol 2011;6:80.

[5] Dahele M, Senan S. The role of stereotactic ablative radiotherapy for earlystage and oligometastatic non-small cell lung cancer: evidence for changing paradigms. Cancer Res Treat 2011;43:75-82.

[6] Hasselle MD, Haraf DJ, Rusthoven KE, Golden DW, Salgia R, Villaflor VM, et al. Hypofractionated image-guided radiation therapy for patients with limited volume metastatic non-small cell lung cancer. J Thorac Oncol 2012;7:376-81.

[7] Higginson DS, Chen RC, Tracton G, Morris DE, Halle J, Rosenman JG, et al. The impact of local and regional disease extent on overall survival in patients with advanced stage IIIB/IV non-small cell lung carcinoma. Int J Radiat Oncol Biol Phys 2012;84:e385-92.

[8] Marks LB, Saynak M, Christodouleas JP. Stage III vs. stage IV lung cancer: "Crossing a Great Divide". Lung Cancer 2010;67:1-3.

[9] Milano MT, Katz AW, Zhang H, Okunieff P. Oligometastases treated with stereotactic body radiotherapy: long-term follow-up of prospective study. Int J Radiat Oncol Biol Phys 2012;83:878-86.

[10] Tree AC, Khoo VS, Eeles RA, Ahmed M, Dearnaley DP, Hawkins MA, et al. Stereotactic body radiotherapy for oligometastases. Lancet Oncol 2013;14:e28-37.

[11] De Ruysscher D, Wanders R, van Baardwijk A, Dingemans AM, Reymen B, Houben R, et al. Radical treatment of non-small-cell lung cancer patients with synchronous oligometastases: long-term results of a prospective phase II trial (NCT01282450). J Thorac Oncol 2012;7:1547-55.

[12] Keast D. Immunosurveillance and cancer. Lancet 1970;2:710-2.

[13] Demaria S, Bhardwaj N, McBride WH, Formenti SC. Combining radiotherapy and immunotherapy: a revived partnership. Int J Radiat Oncol Biol Phys 2005;63:655-66

[14] Formenti SC, Demaria S. Radiation therapy to convert the tumour into an in situ vaccine. Int J Radiat Oncol Biol Phys 2012;84:879-80.
[15] McBride WH, Chiang CS, Olson JL, Wang CC, Hong JH, Pajonk F, et al. A sense of danger from radiation. Radiat Res 2004;162:1-19.

[16] Chakraborty M, Abrams SI, Camphausen K, Liu K, Scott T, Coleman CN, et al. Irradiation of tumour cells up-regulates Fas and enhances CTL lytic activity and CTL adoptive immunotherapy. J Immunol 2003;170:6338-47.

[17] Garnett, Palena C, Chakraborty M, Tsang KY, Schlom J, Hodge JW. Sublethal irradiation of human tumour cells modulates phenotype resulting in enhanced killing by cytotoxic T lymphocytes. Cancer Res 2004;64:7985-94.

[18] Apetoh L, Ghiringhelli F, Tesniere A, Criollo A, Ortiz C, Lidereau R, et al. The interaction between HMGB1 and TLR4 dictates the outcome of anticancer chemotherapy and radiotherapy. Immunol Rev 2007;220:47-59.

[19] Obeid M, Tesniere A, Ghiringhelli F, Fimia GM, Apetoh L, Perfettini JL, et al. Calreticulin exposure dictates the immunogenicity of cancer cell death. Nat Med 2007;13:54-61.

[20] Reits EA, Hodge JW, Herberts CA, Groothuis TA, Chakraborty M, Wansley EK, et al. Radiation modulates the peptide repertoire, enhances MHC class I expression, and induces successful antitumour immunotherapy. J Exp Med 2006;203:1259-71.

[21] Kroemer G, Zitvogel L. Abscopal but desirable: the contribution of immune responses to the efficacy of radiotherapy. Oncoimmunology 2012;1:407-8.

[22] Masucci GV, Wersäll P, Kiessling R, Lundqvist A, Lewensohn R. Stereotactic Ablative Radio Therapy (SABR) followed by immunotherapy a challenge for individualized treatment of metastatic solid tumours. J Transl Med 2012;10:104.

[23] Mole RH. Whole body irradiation; radiobiology or medicine? $\mathrm{Br}$ J Radiol 1953;26:234-41.

[24] Postow MA, Callahan MK, Barker CA, Yamada Y, Yuan J, Kitano S, et al. Immunologic correlates of the abscopal effect in a patient with melanoma. $\mathrm{N}$ Engl J Med 2012;366:925-31.

[25] Stamell EF, Wolchok JD, Gnjatic S, Lee NY, Brownell I. The abscopal effect associated with a systemic anti-melanoma immune response. Int J Radiat Oncol Biol Phys 2013;85:293-5, http://dx.doi.org/10.1016/j.ijrobp.2012.03.017 [Epub 2012 May 5].

[26] Kachikwu EL, Iwamoto KS, Liao YP, DeMarco JJ, Agazaryan N, Economou JS, et al. Radiation enhances regulatory $\mathrm{T}$ cell representation. Int J Radiat Oncol Biol Phys 2011;81:1128-35.

[27] Kwon ED, Hurwitz AA, Foster BA, Madias C, Feldhaus AL, Greenberg NM, et al. Manipulation of $T$ cell costimulatory and inhibitory signals for immunotherapy of prostate cancer. Proc Natl Acad Sci U S A 1997;94:8099-103.

[28] Hodi FS, O’Day SJ, McDermott DF, Weber RW, Sosman JA, Haanen JB, et al. Improved survival with ipilimumab in patients with metastatic melanoma. $\mathrm{N}$ Engl J Med 2010;363:711-23.

[29] Robert C, Thomas L, Bondarenko I, O’Day S, Weber J, Garbe C, et al. Ipilimumab plus dacarbazine for previously untreated metastatic melanoma. N Engl J Med 2011:364:2517-26.

[30] Kantoff PW, Higano CS, Shore ND, Berger ER, Small EJ, Penson DF, et al. Sipuleucel-T immunotherapy for castration-resistant prostate cancer. N Engl J Med 2010;363:411-22.

[31] Kantoff PW, Schuetz T], Blumenstein BA, Glode LM, Bilhartz DL, Wyand M, et al Overall survival analysis of a phase II randomized controlled trial of a Poxviralbased PSA-targeted immunotherapy in metastatic castration-resistant prostate cancer. J Clin Oncol 2010;28:1099-105.

[32] Flemming A. Immunotherapy: a vaccine for prostate cancer? Nat Rev Cancer 2011;11:539.

[33] Rini BI, Halabi S, Rosenberg JE, Stadler WM, Vaena DA, Archer L, et al. Phase III trial of bevacizumab plus interferon Alfa versus interferon Alfa monotherapy in patients with metastatic renal cell carcinoma: final results of CALGB 90206. J Clin Oncol 2010;28:2137-43.

[34] Liu L, Zhang W, Qi X, Li H, Yu J, Wei S, et al. Randomized study of autologous cytokine-induced killer cell immunotherapy in metastatic renal carcinoma. Clin Cancer Res 2012;18:1751-9.

[35] Moudgil T, Bell RB, Leidner R, Van de Ven R, Feng Z, Affentoulis M, et al Developing an immunotherapy strategy for the effective treatment of patients with squamous cell carcinoma of the head and neck. J Immuno Ther 2013;1: P262.

[36] Nizard M, Sandoval F, Badoual C, Pere H, Terme M, Hans S, et al. Immunotherapy of HPV-associated head and neck cancer: critical parameters. Oncoimmunology 2013;2:e24534.

[37] Lee Y, Auh SL, Wang Y, Burnette B, Wang Y, Meng Y, et al. Therapeutic effects of ablative radiation on local tumour require CD8+ T cells: changing strategies for cancer treatment. Blood 2009;114:589-95.

[38] Lugade AA, Moran JP, Gerber SA, Rose RC, Frelinger JG, Lord EM. Local radiation therapy of B16 melanoma tumours increases the generation of tumour antigenspecific effector cells that traffic to the tumor. J Immunol 2005;174:7516-23.

[39] Demaria S, Kawashima N, Yang AM, Devitt ML, Babb JS, Allison JP, et al. Immune-mediated inhibition of metastases after treatment with local radiation and CTLA- 4 blockade in a mouse model of breast cancer. Clin Cancer Res 2005;11:728-34.

[40] Dewan MZ, Galloway AE, Kawashima N, Dewyngaert JK, Babb JS, Forment SC, et al. Fractionated but not single-dose radiotherapy induces an immunemediated abscopal effect when combined with anti-CTLA- 4 antibody. Clin Cancer Res 2009;15:5379-88.

[41] Verbrugge I, Hagekyriakou J, Sharp LL, Galli M, West A, McLaughlin NM et al. Radiotherapy increases the permissiveness of established mammary tumours to rejection by immunomodulatory antibodies. Cancer Res 2012;72: 3163-74. 
[42] Deng L, Liang H, Burnette B, Beckett M, Darga T, Weichselbaum RR, et al. Irradiation and anti-PD-L1 treatment synergistically promote antitumour immunity in mice. J Clin Invest 2014;124:687-95.

[43] Demaria S, Ng B, Devitt ML, Babb JS, Kawashima N, Liebes L, et al. Ionizing radiation inhibition of distant untreated tumours (abscopal effect) is immune mediated. Int J Radiat Oncol Biol Phys 2004;58:862-70.

44] Shiraishi K, Ishiwata Y, Nakagawa K, Yokochi S, Taruki C, Akuta T, et al. Enhancement of antitumour radiation efficacy and consistent induction of the abscopal effect in mice by ECI301, an active variant of macrophage inflammatory protein-1alpha. Clin Cancer Res 2008;14:1159-66.

[45] Everse LA, Bernsen MR, Dullens HF, Den Otter W. Priming of the antitumour response promotes efficacy of interleukin-2 therapy. Cancer Immunol Immunother 1997;44:221-9.

[46] Jurgenliemk-Schulz IM, Renes IB, Rutgers DH, Everse LA, Bernsen MR, Den Otter $\mathrm{W}$, et al. Anti-tumour effects of local irradiation in combination with peritumoral administration of low doses of recombinant interleukin-2 (rIL-2). Radiat Oncol Invest 1997;5:54-61.

[47] Frey B, Schildkopf P, Rödel F, Weiss EM, Munoz LE, Herrmann M, et al. Annexin A5 renders dead tumour cells immunogenic: implications for multimodal cancer therapies. J Immunotoxicol 2009;6:209-16.

[48] Witek M, Blomain ES, Magee MS, Xiang B, Waldman SA, Snook AE. Tumour radiation therapy creates therapeutic vaccine responses to the colorectal cancer antigen GUCY2C. Int J Radiat Oncol Biol Phys 2014;88:1188-95.
[49] Golden EB, Demaria S, Schiff PB, Chachoua A, Formenti SC. An abscopal response to radiation and ipilimumab in a patient with metastatic non-small cell lung cancer. Cancer Immunol Res 2013;1:365-72.

[50] Hiniker SM, Chen DS, Knox SJ. Abscopal effect in a patient with melanoma. N Engl J Med 2012;366:2035 [author reply 2035-6].

[51] Stamell EF, Wolchok JD, Gnjatic S, Lee NY, Brownell I. The abscopal effect associated with a systemic anti-melanoma immune response. Int J Radiat Oncol Biol Phys 2013;85:293-5.

[52] Slovin SF, Higano CS, Hamid O, Tejwani S, Harzstark A, Alumkal JJ, et al. Ipilimumab alone or in combination with radiotherapy in metastatic castration-resistant prostate cancer: results from an open-label, multicenter phase I/II study. Ann Oncol 2013;24:1813-21.

[53] Kwon ED, Drake CG, Scher HI, Fizazi K, Bossi A, van den Eertwegh AJ, et al. Ipilimumab versus placebo after radiotherapy in patients with metastatic castration-resistant prostate cancer that had progressed after docetaxel chemotherapy (CA184-043): a multicentre, randomised, double-blind, phase 3 trial. Lancet Oncol 2014;15:700-12, http://dx.doi.org/10.1016/S1470-2045(14)70189-5 [Epub 2014 May 13].

[54] Registry and results database of publicly and privately supported clinical studies of human participants conducted around the world. Bethesda, MD: US National Institutes of Health ${ }^{\odot} ; 2014$. www.clinicaltrials.gov [home page on Internet]. 